\title{
Analisis sistem pengendalian internal pada sistem penggajian karyawan (studi kasus pada CV Surya Jaya Abadi)
}

\author{
Tri Haryadi*; Eko Triyanto
}

\author{
Program Studi Akuntansi, STIE Surakarta \\ *E-mail korespodensi: Triharyadi1@gmail.com
}

\begin{abstract}
This study aims to determine the internal control system at CV Surya Jaya Abadi, the procedures applied in the employee payroll process, and to find out the weaknesses of the procedures that have been implemented. This research uses a descriptive qualitative method with a case study approach, data obtained from observations, interviews, and documentation. The results of this study are the control system at CV Surya Jaya Abadi has been running quite effectively, although there are weaknesses found, among others, there is no separation of duties and authorities related to payroll, everything is done by the HRD department, there is no written internal payroll control system. as a guide in the payroll process, as well as a computerized payroll system that is not yet connected to the attendance system. Payroll problems that occur at CV Surya Jaya Abadi are salary errors, many are caused by human factors, including employees who have not been orderly absent through the fingerprint machine and errors in inputting the components of salary and attendance by the payroll section, namely HRD because the payroll system is separate from absences.
\end{abstract}

Keywords: Payroll, System, Internal control

\begin{abstract}
Abstrak
Penelitian ini bertujuan untuk mengetahui sistem pengendalian internal pada CV Surya Jaya Abadi, prosedur yang diterapkan dalam proses penggajian karyawan, serta mengetahui kelemahan dari prosedur yang telah diterapkan. Penelitian ini menggunakan metode kualitatif deskriptif dengan pendekatan studi kasus, data diperoleh dari hasil pengamatan, wawancara dan dokumentasi. Hasil dari penelitian ini adalah sistem pegendalian pada CV Surya Jaya Abadi sudah berjalan cukup efektif, walaupun ada kelemahan yang ditemukan antara lain, belum ada pemisahan tugas dan wewenang yang berhubungan dengan penggajian, semua dikerjakan oleh bagian HRD, belum ada sistem pengendalian penggajian internal yang tertulis sebagai pedoman dalam proses penggajian, serta sistem penggajian terkomputerisasi yang belum terhubung dengan sistem absensi. Permasalahan penggajian yang terjadi di CV Surya Jaya Abadi yaitu kesalahan gaji, banyak disebabkan oleh faktor manusia antara lain karyawan belum tertib melakukan absen melalui mesin fingerprint serta kesalahan peginputan komponen gaji serta absensi oleh bagian penggajian yaitu HRD karena sistem penggajian terpisah dengan absensi.
\end{abstract}

Kata kunci: Penggajian, Sistem, Pengendalian internal

\section{PENDAHULUAN}

Sebuah perusahaan yang menjalankan kegiatan operasionalnya, tentu memilki suatu aturan yang digunakan sebagai alat kontrol dan pengawasan terhadap kegiatan operasional perusahaan, dalam hal ini yaitu mengenai sistem pengendalian internal 
perusahaan. Salah satu aspek sistem pengendalian internal yang ada dalam perusahaan adalah mengenai pengendalian pada proses penggajian karyawan.

Penggajian karyawan merupakan salah satu aspek penting dalam perusahaan karena aspek ini menyangkut kesejahteraan, semangat kerja serta prestasi kerja karyawan sehingga akan mempengaruhi karyawan. Gaji yang akan diterima oleh setiap karyawan setiap bulannya harus benar sesuai dengan jam kerja dan hari kerja yang telah dipenuhi oleh karyawan agar tidak terjadi komplain yang mengakibatkan menurunnya kualitas kerja karyawan tersebut. (Rosdiana Pane,2015)

Proses penggajian pada karyawan disuatu perusahaan umumnya meliputi beberapa tahapan diantaranya perhitungan gaji, pencatatan gaji, dan pembayaran gaji, dimana setiap prosesnya sangat rawan terjadi kesalahan yang disebabkan oleh kurangnya ketelitian bagian yang mengerjakan penggajian dan bahkan bisa terjadi kecurangan bila proses penggajian tersebut tidak dikelola dengan baik. Proses penggajian yang baik akan tercapai apabila pada proses penggajian telah mempunyai sistem pengendalian internal yang efektif, sehingga prosedur penggajian dapat sesuai dengan yang telah ditetapkan oleh perusahaan. (Rosdiana Pane, 2015)

CV Surya Jaya Abadi merupakan perusahaan yang sedang berkembang yang bergerak dalam bidang jual beli perhiasan. Sama seperti perusahaan pada umumnya perusahaan ini juga melakukan proses penggajian setiap bulannya, proses penggajian pada perusahaan ini telah menggunakan sistem yang terkomputerisasi sehingga mudah dalam perhitungannya. Walaupun demikian setiap bulannya perusahaan ini selalu mendapatkan komplain dari karyawan di perusahaan tersebut akibat kesalahan perhitungan gaji, karena kesalahan penggajian tersebut maka kekurangan atau kelebihan akan diberikan di penggajian bulan berikutnya. Permasalahan tersebut yang menarik peneliti untuk melakukan penelitian mengenai proses penggajian di CV. Surya Jaya Abadi.

Beberapa penelitian terdahulu mengenai sistem penggendalian internal penggajian diantaranya yaitu penelitian oleh I Komang Juni Indrawan, Ni Kadek Sinarwati dan Edy Sujana (2017) dengan judul "Analisis Sistem Pengendalian Intern Pada Penggajian Karyawan PT PLN (Persero) Area Bali Utara", hasil dari penelitian tersebut adalah sistem penggajian telah dilakukan dengan baik, unsur-unsur pengendalian internalnya sudah terpenuhi serta sistem penggajian sudah terkomputerisasi dengan SAP yang sudah terhubung dengan baik. Kemudian Penelitian oleh Rosdiana (2015) dengan judul "Analisis Pengendalian Internal Pada Proses Penggajian Studi Pada CV Genta Shamballa", hasil dari penelitian ini yaitu sistem pengendalian internal mengenai proses penggajian dalam aspek struktur organisasinya sudah layak, proses penggajian telah dilakukan dengan sistem dan prosedur yang baik, serta kualitas karyawan yang terdapat dalam perusahaan sudah sesuai dengan bidangnya. Selanjutnya adalah penelitian dari Sulung Yogy Hardhanto, David Paul Elia Saerang dan Harijanto Sabijono (2015), yang berjudul "Analisis Sistem Pengendalian Intern Penggajian Karyawan Pada PT. BPR Prisma Dana" yang mengemukakan bahwa berdasarkan penelitannya, pada proses penggajian BPR Prisma Dana telah melakukan pemisahan tugas serta tanggungjawab fungsional pada karyawan. Prosedur penggajian pada BPR Prisma Dana sudah berjalan dengan cukup efisien. Selanjutnya adalah penelitian oleh Retno Wulandari (2018) yang berjudul "Analisis SistemPengendalian Internal Penggajian Pada PT Usaha Tani Maju" hasil dari riset ini adalah PT Usaha Tani Maju masih menggunakan sistem penggajian secara manual sehingga proses penggajiannya masih kurang efektif, pegendalian internal dalam penggajian sudah dijalankan dengan cukup baik, akan tetapi masih perlu adanya pemisahan tugas sesuai dengan fungsionalnya agar tidak terjadi perangkap jabatan. Penelitian terdahulu selanjutnya adalah penelitian oleh Ismi Dwi Utami (2019) yang berjudul "sistem pengendalian internal pada siklus penggajian (studi kasus PT Pegadaian Cabang Pelayanan Sumenep)", hasil riset tersebut 
adalah pengendalian internal penggajian yang dijalankan di perusahaan belum seluruhnya sama dengan teori pengendalian internal dari Mulyadi, karena ada ketidaksesuaian pada aspek organisasi, aspek sistem otorisasi serta aspek praktik yang sehat.

Berdasarkan beberapa penelitian terdahulu, perbedaan penelitian ini dengan penelitian sebelumnya adalah penelitian ini ingin lebih mengungkap fenomena yang ada yaitu apa yang menyebabkan CV Surya Jaya Abadi sering mengalami kesalahan penggajian padahal perusahaan ini sudah memiliki sistem penggajian yang terkomputerisasi.Selain itu peneliti ingin mengetahui mengapa CV Surya Jaya Abadi dalam proses penggajiannya belum memiliki sistem pengendalian internal yang tertulis yang mengatur secara khusus mengenai proses penggajian di perusahaan ini. Dari beberapa hal inilah yang menjadikan perhatian bagi peneliti untuk melakukan penelitian lebih mendalam mengenai proses penggajian di CV Surya Jaya Abadi.Hal ini sebagai dasar peneliti membuat rancangan sistem pengendalian internal tertulis

Penelitian ini bertujuan untuk mengetahui sistem pengendalian internal perusahaan CV Surya Jaya Abadi serta prosedur yang diterapkan dalam proses penggajian karyawan, serta mengetahui kelemahan dari prosedur yang telah diterapkan dalam perusahaan tersebut. Penelitian ini diharapkan bermanfaat bagi perusahaan, sehingga perusahaan tersebut dapat melakukan perbaikan pada sistem yang telah diterapkan.Penelitian ini akan menghasilkan berupa rancangan sistem pengendalian internal penggajian tertulis yang dapat dijadikan bahan pertimbangan dan evaluasi perusahaan demi keefektifan serta kelancaran sistem pengendalian internal terhadap penggajian di CV Surya Jaya Abadi kedepannya.

\section{LANDASAN TEORI}

\section{Sistem pengendalian internal}

Sistem pengendalian internal menurut mulyadi (2016:129) adalah meliputi struktur organisasi, metode dan ukuran-ukuran yang dikoordinasikan untuk menjaga aset organisasi, ketelitian dan keandalan data akuntansi, mendorong efisiensi dan mendorong dipatuhinya kebijakan manajemen.

Pengendalian internal memiliki beberapa tujuan, menurut Mulyadi (2016:129) tujuan sistem pengendalian antara lain: 1).Menjaga kekayaan organisasi, 2).Mengecek ketelitian dan keandalan data akuntansi, 3).Mendorong efisiensi, 4).Mendorong dipatuhinya kebijakan manajemen.

Komponen-komponen dalam pengendalian internal menurut COSO (Committee of Sponsoring Organization of The Treadway Commission) (2013) meliputi: 1). A control environment (lingkungan pengendalian), 2).Risk assesment (penilaian resiko), 3).Control activities (kegiatan pengendalian), 4).Information and communication (informasi dan komunikasi), 5).Monitoring (pemantauan)

\section{Sistem penggajian}

Sistem penggajian menurut Mulyadi (2016:340) adalah serangkaian kegiatan bisnis dan operasi yang bertujuan untuk menyelesaikan segala transaksi pembayaran dan penyerahan jasa yang dilakukan karyawan yang memiliki jenjang jabatan manajer.

Dokumen-dokumen yang dibutuhkan dalam sistem penggajian menurut Mulyadi (2016:310) antara lain: 1).Dokumen pendukung perubahan gaji. 2).Kartu jam hadir, 3).Kartu jam kerja, 4).Daftar gaji, 5).Rekap daftar gaji, 6).Surat pernyataan gaji, 7).Amplop gaji, 8).Bukti kas keluar.

Unsur pengendalian internal dalam sistem penggajian menurut Mulyadi (2016:321) antara lain: Organisasi: 1).Fungsi pembuat daftar gaji dan upah harus terpisah dari fungsi keuangan. 2).Fungsi pencatatan waktu hadir harus terpisah dari fungsi operasi.

Sistem Otorisasi: 1).Setiap orang yang tercantum dalam daftar gaji dan upah harus memiliki surat keputusan pengangkatan sebagai karyawan perusahaan yang 
ditandatangani oleh Direktur Utama, 2).Setiap perubahan gaji dan upah karena perubahan pangkat, perubahan tarif gaji dan upah, tambahan keluarga harus didasarkan pada surat keputusan Direktur Keuangan. 3).Setiap potongan atas gaji dan upah karyawan selain dari pajak penghasilan karyawan harus didasarkan atas surat potongan gaji dan upah yang diotorisasi oleh fungsi kepegawaian. 4).Kartu jam hadir diotorisasi oleh fungsi pencatat waktu. 5).Perintah lembur harus diotorisasi oleh kepala departemen karyawan yang bersangkutan. 6).Daftar gaji dan upah harus diotorisasi oleh fungsi personalia. 7).Bukti kas keluar untuk pembayaran gaji dan upah harus diotorisasi fungsi akuntansi.

Prosedur pencatatan: 1).Perubahan dalam catatatn penghasilan karyawan direkonsiliasi dengan daftar gaji dan upah karyawan. 2).Tarif upah yang dicantumkan dalam kartu jam kerja diverifikasi ketelitiannya oleh fungsi akuntansi.

Praktik yang sehat: 1).Kartu jam hadir harus dibandingkan dengan kartu jam kerja sebelum kartu yang terakhir ini dipakai sebagai dasar distribusi biaya tenaga kerja langsung. 2).Pemasukan kartu jam hadir ke dalam mesin pencatatan waktu harus diawasi oleh fungsi pencatat waktu. 2).Pembuatan daftar gaji dan upah harus diverifikasi kebenaran dan ketelitian perhitungannya oleh fungsi akuntansi sebelum dilakukan pembayaran. 2).Perhitungan pajak penghasilan karyawan direkonsiliasi dengan catatan pengahasilan karyawan. 3).Catatan pengahasilan karyawan disimpan oleh fungsi pembuat daftar gaji dan upah.

Adapun jaringan prosedur sistem akuntansi penggajian menurut Mulyadi (2016:319-320) adalah sebagai berikut: 1).Prosedur pencatatan waktu hadir, 2).Prosedur pembuatan daftar gaji. 3).Prosedur distribusi biaya gaji. 4).Prosedur pembuatan bukti kas keluar, 5).Prosedur pembayaran gaji.

\section{Kerangka pemikiran}

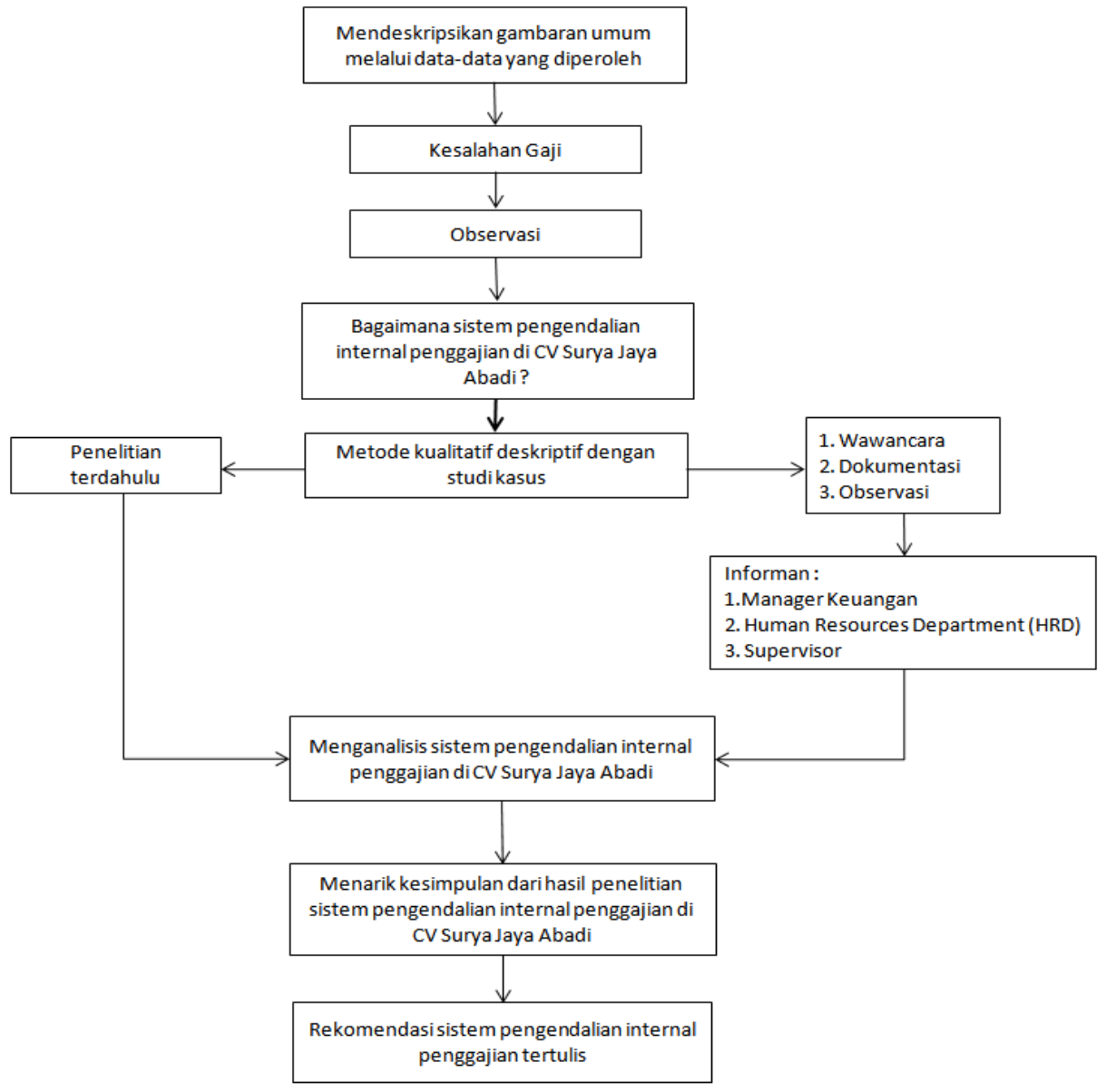

Gambar 1. Kerangka pemikiran 


\section{METODE}

\section{Obyek penelitian}

Obyek dari penelitian ini adalah CV Surya Jaya Abadi yang beralamatkan di Jalan HOS Cokroaminoto No 23, Klaten, Jawa Tengah.

\section{Jenis penelitian dan sumber data}

Penelitian ini adalah penelitian kualitatif dengan pendekatan deskriptif dengan studi kasus yaitu studi kasus pada CV Surya Jaya Abadi. Sumber data yang digunakan dalam penelitian ini adalah data primer dan data sekunder. Data primer yang digunakan di penelitaian ini adalah data hasil observasi serta data hasil wawancara dengan semua informan mengenai sistem pengendalian internal pada penggajian di CV Surya Jaya Abadi. Data primer yang sudah diolah lebih lanjut dan disajikan baik oleh pengumpul data primer atau pihak lain.

\section{Metode pengumpulan data}

\section{Observasi}

Melakukan pengamatan mengenai sistem penggendalian internal dan proses penggajian yang ada di CV Surya Jaya Abadi

\section{Wawancara}

Melakukan tanya jawab terhadap informan yang berkaitan mengenai penggajian di CV Surya Jaya Abadi yaitu general manager keuangan, human resources departemen (HRD) dan supervisor

\section{Dokumentasi}

Mengumpulkan dokumen-dokumen CV Surya Jaya Abadi yang di butuhkan dan berkaitan dengan penelitian.

\section{Teknik dan langkah-langkah penelitian}

Teknik penelitian yang digunakan dalam penelitian ini adalah kualitatif deskriptif. Hasil penelitian akan digambarkan serta diurai sesuai dengan landasan teori yang dibuat, sehingga peneliti dapat mengetahui pelaksanaan dari sistem pengendalian internal penggajian yang ada di CV Surya Jaya Abadi. Dari hasil tersebut peneliti dapat mengetahui kelemahan apa yang ditemukan dalam sistem pengendalian internal penggajian yang telah diterapkan.

\section{HASIL DAN PEMBAHASAN}

\section{Gambaran umum objek penelitian}

CV. Surya Jaya Abadi merupakan perusahaan swasta yang bergerak dalam bidang perdagangan ritel yaitu jual beli perhiasan yang berdiri pada tahun 1980. Perusahaan ini beralamatkan di Jalan HOS Cokroaminoto no 23 Klaten, Jawa Tengah.CV Surya Jaya Abadi telah memiliki 15 Cabang toko yang tersebar di wilayah Klaten, Solo, Yogyakarta dan Boyolali. Perusahaan ini menyediakan berbagai jenis produk diantaranya perhiasan dengan kadar 45\%, 75\%, 91,8\% dan 99,99\%, Logam mulia serta berlian. CV Surya Jaya Abadi memiliki slogan yaitu "Investasi Cerdas dan Terpecaya". 


\section{Struktur organisasi}

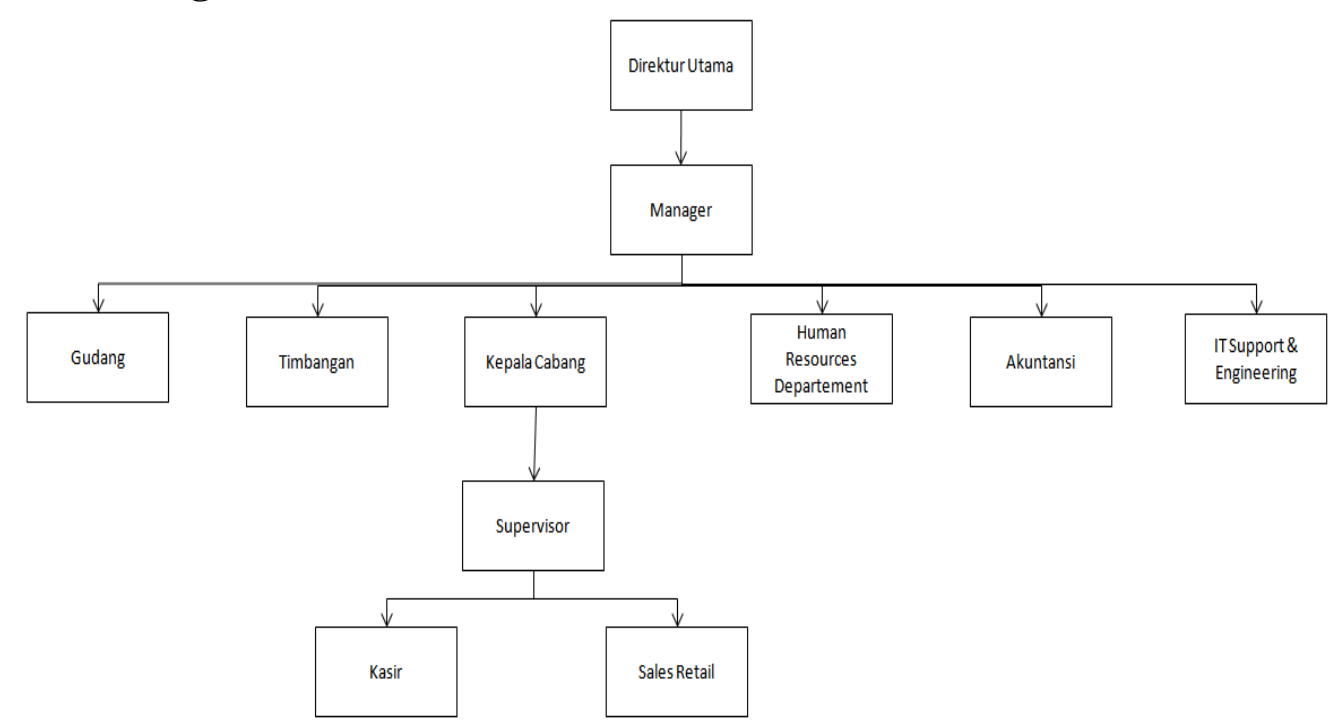

Gambar 2. Struktur organisasi CV Surya Jaya Abadi

\section{Proses penggajian CV Surya Jaya Abadi}

Beberapa dokumen yang dibutuhkan dalam proses penggajian di CV Surya Jaya Abadi anatara lain: 1).Daftar waktu hadir, 2).Dokumen perubahan gaji, 3).Daftar gaji, 3).Rekap daftar gaji, 4).Slip gaji, 5).Amplop

Proses penggajian di CV Surya Jaya Abadi terdiri dari beberapa tahapan antara lain:

\section{Pencatatan waktu hadir}

Pencatatan waktu kehadiran karyawan di CV Surya Jaya Abadi menggunakan fingerprint yang terhubung dengan sistem pencatatan absensi karyawan di bagian HRD, walaupun seperti itu masing-masing cabang tetap membuat absensi manual yang nantinya akan dikirim ke bagian HRD setiap bulannya untuk dicocokkan dengan sistem absensi sebelum dilakukan perhitungan gaji untuk menghindari kesalahan.

\section{Pembuatan daftar gaji}

Komponen gaji akan diinput kedalam sistem penggajian yang sudah terkomputerisasi.Sisem akan menghitung gaji sesuai komponen gaji dan daftar hadir yang diinput, setelah semua data terinput makan daftar gaji telah selesai dibuat. Bagian yang melakukan pembuatan daftar gaji adalah HRD dan daftar gaji akan dicek ulang dan diotorisasi bagian keuangan.

\section{Penggajian}

Penggajian di CV Surya Jaya Abadi dilakukan dengan cara tunai dan transfer bank. Untuk pembayaran tunai, pihak yang melakukan perhitungan uang adalah bagian HRD yang akan dihitung sesuai daftar gaji yang telah dibuat, sementara untuk penggajian transfer, daftar gaji akan diserahkan kepada pihak bank dan di otorisasi langsung oleh pemilik.Dari daftar gaji yang telah dibuat akan dibuat rekap gaji untuk mengetahui total gaji yang dikeluarkan untuk dilaporkan kebagian akuntansi dalam hal ini bagian akuntansi hanya menerima rekap total gaji dan tidak melakukan pengecekan saat proses penggajian.

\section{Sistem pengendalian internal pada penggajian CV Surya Jaya Abadi}

Berikut ini adalah hasil analisis sistem pengendalian internal penggajian di CV Surya Jaya Abadi : 


\section{Aspek organisasi}

Dari hasil pengamatan serta wawancara dari aspek organisasi, CV Surya Jaya Abadi belum ada pemisahan fungsi antara pembuatan daftar gaji dan bagian keuangan atau yang melakukan penggajian. Selain itu pihak yang melakukan pencatatan kehadiran tidak terpisah dari fungsi operasi.Hal ini dapat mengganggu kinerja karyawan yang tidak terfokus pada satu fungsi, selain itu tidak adanya pemisahan tugas pembuat daftar gaji dan keuangan dapat memunculkan resiko penyelewengan.

\section{Aspek sistem otorisasi}

Sistem otorisasi di CV Surya Jaya Abadi sudah berjalan dengan cukup baik, karena dari awal proses penggajian pada pembuatan daftar hadir, daftar gaji, perhitungan gaji dan rekap gaji serta pembayarannya selalu dicek oleh bagian yang berwenang untuk mengurangi tingkat kesalahan gaji dan penyelewengan. Hal ini dibuktikan dengan wawancara dengan bagian yang terkait dengan penggajian dan hasilnya adalah sebagai berikut: 1).Setiap karyawan yang terdapat dalam daftar gaji tidak memiliki surat keputusan pengangkatan yang ditandatangani oleh Direktur utama, karena kebanyakan karyawan adalah dengan sistem kontrak. 2).Perubahan gaji karyawan selalu didasarkan pada keputusan pemilik sehingga dapat terkontrol. 3).Potongan pada gaji karyawan telah diotorisasi oleh pihak yang berwenang, dalam hal ini potongan berupa kas bon karyawan, penggantian barang hilang, penggantian akibat kesalahan transaksi dan potongan tunjangan BPJS. 3).Perusahaan tidak menggunakan kartu jam kerja akan tetapi diganti dengan sistem fingerprint dan sistem ini sudah terhubung langsung dengan sistem absensi karyawan di bagian HRD jadi bisa dicek setiap hari. 4).Lembur dalam perusahaan dilaksanakan atas dasar persetujuan dari pimpinan bagian tersebut. 5).Daftar gaji yang telah dibuat selalu diotorisasi oleh manajer. 6).Bukti pengeluaran uang untuk pembayaran gaji akan langsung diotorisasi oleh pemilik.

\section{Aspek prosedur pencatatan}

Prosedur Pencatatan sudah dilakukan dengan cukup baik diantaranya: 1).Setiap terdapat perubahan dalam catatan gaji akan selalu dicocokkan dengan daftar gaji yang telah dibuat. 2).Bagian HRD selalu mencatat setiap perubahan pegawai. 3).Setiap perubahan pegawai selalu dikomunikasikan dengan bagian yang melakukan penggajian, dalam hal ini HRD jugalah yang mempunyai fungsi penggajian karena tidak ada pemisahan tugas seperti yang dijelaskan pada aspek organisasi.

\section{Aspek praktik yang sehat}

Praktik yang sehat di CV Surya Jaya Abadi yang berjalan pada penggajian dibuktikan dengan : a).Waktu kehadiran pada mesin fingerprint dicek oleh bagian HRD secara berkala dengan sistem kehadiran karyawan. b).Daftar gaji dicek kebenaran dan ketelitiannya oleh manager dan pemilik sebelum dilakukan pembayaran. c).Catatan penghasilan pada CV Surya Jaya Abadi disimpan oleh bagian pembuat daftar gaji yaitu bagian HRD. d).Pajak penghasilan karyawan telah direkonsiliasi dengan catatan penghasilan karyawan.

Permasalahan yang muncul yang berkaitan dengan penggajian di CV Surya Jaya Abadi antara lain :

\section{Sistem penggajian}

Sistem penggajian sudah terkomputerisasi akan tetapi sistem penggajian dengan sistem absensi terpisah dan belum terhubung, sehingga absensi setiap karyawan harus diinput secara manual satu persatu. 


\section{Kesalahan gaji karyawan}

Kesalahan perhitungan gaji karyawan adalah hal yang sering terjadi di CV Surya Jaya Abadi, berdasarkan pengamatan peneliti hal ini disebabkan oleh beberapa faktor yaitu:

\section{Faktor manusia}

Faktor manusia adalah hal yang paling sering mengakibatkan kesalahan gaji hal ini dikarenakan masih banyak karyawan yang tidak melakukan absensi dengan alasan lupa, tentu hal ini tidak sesuai SOP perusahaan. Bagian HRD harus mengontrol dan mengawasi setiap hari melalui sistem mereka. Bagian HRD harus teliti dan hati-hati, jika tidak maka akan terjadi kesalahan karyawan yang masuk akan dihitung libur. Kemudian karyawan juga sering tidak melakukan konfirmasi ketika libur mendadak kepada bagian HRD. Faktor manusia lainnya adalah SDM yang berhubungan dengan perhitungan dan penginputan gaji ke sistem penggajian yang sering kali tidak teliti sehingga melakukan kesalahan penginputan komponen gaji dan juga absensi.

\section{Faktor sistem}

Sitstem penggajian yang terkomputerisasi dengan sistem absen tidak terhubung, sehingga harus input manual. Hal ini dapat meningkatkan resiko kesalahan penginputan absen, sehingga harus teliti dan berhati-hati dalam penginputannya.

Perlakuan bagi karyawan yang mengalami kesalahan gaji adalah jika terjadi kelebihan gaji, maka uang kelebihan akan diminta untuk dikembalikan.Sedangkan jika terjadi kekurangan gaji, maka kekurangan tersebut akan dibayar pada penggajian dibulan berikutnya.

Kelemahan Sistem Pengendalian Internal Penggajian CV Surya Jaya Abadi antara lain: 1).Dari sisi organisasi, belum adanya pemisahan fungsi antara pembuat daftar gaji dan keuangan perlu menjadi perhatian, karena hal ini dapat menjadi celah yang memicu penyelewengan pada proses penggajian, mungkin saat ini CV Surya Jaya Abadi belum mengalaminya akan tetapi hal ini mungkin saja bisa terjadi di waktu yang akan datang, sehingga perlu adanya perbaikan. 2).Dari sisi prosedur, CV Surya Jaya Abadi belum memiliki flowchart mengenai alur proses penggajian yang tertulis. Prosedur penggajian mengenai proses penggajian hanya berdasarkan lisan hal ini tentu akan mempengaruhi kinerja karena tidak ada alur yang menjelaskan alur kerja yang benar. 3).CV Surya Jaya Abadi belum memiliki sistem pengendalian internal penggajian secara tertulis.

\section{Rekomendasi sistem pengendalian internal proses penggajian tertulis}

Prosedur pencatatatan waktu hadir terdiri dari kriteria: a).Karyawan wajib datang 15 menit sebelum jam operasional toko untuk melakukan absen melalui mesin fingerprint. b).Bagian HRD wajib mengecek absensi setiap hari melalui sistem absensi. c).Bagian HRD harus melakukan konfirmasi apabila terjadi kejanggalan dalam sistem absensi.

Hal ini meliputi: 1).Karyawan melakukan absensi melebihi dari jam operasional perusahaan yang telah ditetapkan. 2).Karyawan yang libur tidak sesuai jadwal yang telah ditetapkan. Dalam hal ini karyawan tidak melakukan konfimasi serta tidak mengajukan surat tukar libur atau shift ataupun pengajuan cuti kepada bagian HRD. 3).Karyawan hadir tetapi tidak melakukan absensi di mesin fingerprint. 4).Karyawan yang libur melebihi dari jumlah libur yang telah ditentukan oleh perusahaan. 5).Karyawan yang melakukan absensi waktu pulang, kurang dari waktu yang telah ditetapkan oleh perusahaan. 5).Karyawan yang tidak melakukan abesensi melalui fingerprint sebanyak 3 kali dalam sebulan, karyawan akan mendapatkan surat peringatan dari bagian HRD. 6).Bagian HRD wajib mengecek jam lembur apabila ada karyawan yang melakukan lebur. 7).Bagian HRD membuat daftar kehadiran kerja karyawan secara harian dan 
direkap bulanan sesuai dengan sistem absensi. 8).Bagian HRD menghitung jam lebur karyawan yang telah melakukan lembur, sesuai dengan peraturan yang telah ditetapkan. 9).Daftar kehadiran karyawan yang telah direkap wajib dicocokkan dengan buku absen manual yang telah dibuat oleh supervisor. 10). Apabila ada ketidaksesuaian maka HRD wajib segera konfirmasi ke supervisor dan melakukan revisi jika terjadi kesalahan. 11).Daftar kehadiran karyawan yang telah dicocokan harus diotorisasi oleh kepala bagian HRD. 12).Daftar kehadiran karyawan terotorisasi akan menjadi dasar perhitungan gaji karyawan.

\section{Prosedur pembuatan daftar gaji.}

Pembuatan daftar gaji terdiri beberapa prosedur yaitu: a).Bagian pembuat daftar gaji karyawan adalah bagian HRD. b).Daftar kehadiran karyawan terotorisasi menjadi dasar pembuatan daftar gaji karyawan. c).Karyawan yang dimasukkan kedalam daftar gaji harus sesuai dengan daftar karyawan yang ada di bagian personalia. d).Setiap ada karyawan baru yang bekerja harus disertai buki kontrak kerja yang telah di tanda tangani oleh pemilik. e).Setiap potongan gaji yang akan dikurangkan kedalam komponen gaji karyawan harus disetujui oleh manajer dan kepala bagian HRD.

Potongan gaji karyawan meliputi: 1).Penggantian atas kehilangan barang dagangan perusahaan. 2).Potongan jaminan kesehatan dan ketenagakerjaan, 3).Kas bon karyawan. 4).Penggantian atas kerusakan aset perusahaan yang dilakukan karyawan. 5).Potongan lainnya yang mengakibatkan kerugian perusahaan secara material. 6).Setiap ada perubahan gaji karyawan wajib berdasarkan surat keterangan yang telah disetujui oleh pemilik. 7).Komponen gaji yang dimasukan ke dalam sistem penggajian harus sesuai dengan ketetapan yang telah ditetapkan oleh perusahaan. 8).Semua komponen gaji harus dimasukkan kedalam sistem penggajian dengan tepat, cermat, teliti dan sesuai, agar menghindari kemungkinan resiko kesalahan gaji. 9).Perhitungan masing-masing komponen harus dicocokkan dengan nama karyawan yang bersangkutan agar menghidari kesalahan gaji. 10).Pembuatan daftar gaji harus dipisah antara daftar gaji untuk karyawan dengan pembayaran secara transfer bank dan karyawan dengan pembayaran gaji secara tunai. 11).Pembuatan daftar gaji harus dipisah berdasarkan cabang dan departemen bagian yang ada didalam perusahaan. 12).Daftar gaji yang telah selesai dibuat harus dikoreksi ulang kebenaran perhitungan serta penginputannya. 13).Daftar gaji yang telah dikoreksi wajib diotorisasi oleh kepala bagian HRD yang kemudian akan dilaporkan pada manajer.

\section{Prosedur pembayaran gaji.}

Pembayaran gaji terdiri dari beberapa prosedur diantaranya: 1).Daftar gaji yang telah diotorisasi oleh kepala HRD serta persetujuan dari pejabat yang berwenang adalah dasar dari distribusi gaji. 2). Berikut prosedur berdasarkan cara pembayaran gaji karyawan.

\section{Pembayaran secara transfer.}

Pembayaran secara transfer terdiri dari: 1).Bagian HRD membuat daftar rekening bank karyawan dan mengisi jumlah nominal gaji yang akan ditransfer ke karyawan tersebut. 2).Daftar rekening bank beserta nominal gaji yang telah dibuat harus dicek dan di otorisasi oleh manager dan pemilik. 3).Daftar gaji yang telah diotorisasi serta disetujui oleh manajer dan pemilik akan dilaporkan kepada pihak bank. 4).Proses pembayaran transfer gaji di approve langsung oleh pemilik. 5).Surat keterangan gaji (slip gaji) dibuat dan dicetak oleh bagian HRD. 6).Surat keterangan gaji dikemas dalam amplop dan dikirim ke pada supervisor serta kepala departemen. 7).Amplop yang sudah terisi surat 
keterangan gaji, dikelompokkan berdasarkan cabang dan departemen untuk mempermudah pendistribusiannya. 8).Supervisor serta kepala departemen membagikan slip gaji pada tanggal yang sama dengan tanggal pembayaran gaji. 9).Setiap kesalahan gaji dengan metode pembayaran transfer, pembetulan gaji akan dilakukan pada periode penggajian berikutnya.

\section{Pembayaran secara tunai.}

Pembayaran secara tunai terdiri dari: 1).Bagian yang bertugas menghitung gaji tunai adalah HRD, 2).Kas tunai diambil dari kasir atas persetujuan manajer.Kas tunai dihitung berdasarkan daftar gaji yang telah dibuat dan telah di otorisasi, 3).Kas tunai yang telah dihitung harus dicek ulang untuk menghindari kesalahan penggajian. 4).Surat keterangan gaji karyawan (slip gaji) dibuat dan dicetak oleh bagian HRD. 5).Kas tunai akan dimasukkan kedalam amplop beserta surat keterangan gaji karyawan (slip gaji) sesuai nama karyawan. 6).Ampop yang telah terisi uang tunai serta surat keterangan gaji (slip gaji) dikelompokkan berdasarkan daftar gaji nya agar mempermudah proses distribusi gaji. 7).Amplop harus dikirim ke supervisor dan kepala departemen bagian pada tanggal terakhir pada bulan berjalan. 8).Amplop diberikan oleh supervisor dan kepala departemen bagian kepada karyawan pada tanggal terakhir pada bulan berjalan pada saat pulang kerja. 9).Kesalahan gaji pada pembayaran secara tunai akan dilakukan revisi pada penggajian periode berikutnya. 10).Setelah proses perhitungan gaji selesai ,sisa uang kas tunai yang masih dibawa harus dicocokkan dengan daftar gaji yang ada., 11).Sisa uang harus pas saat dikembalikan ke kasir , sesuai dengan mutasi daftar gaji yang telah dikeluarkan dan melaporkan ke manajer. 12).Apapila terjadi kekurangan saat pengembalian, bagian HRD wajib melakukan penggatian sesuai dengan kekurangan kas. 13).Apabila ditemukan penyelewengan dan kecurangan dalam proses pembayaran gaji, yang mengakibatkan kerugian perusahaan secara material, pihak manajemen perusahaan akan memberikan sanksi yang tegas. 14).Pembayaran gaji karyawan harus tepat waktu yaitu paling lambat tanggal terakhir pada bulan periode gaji. 15).Setiap komplain gaji karyawan, karyawan melaporkan kepada supervisor atau kepala bagian departemennya. 16).Supervisor dan kepala bagian departemen akan melakukan konfirmasi kepada bagian HRD atas komplain yang diterima. 17).Bagian HRD wajib memeriksa perhiungan gaji serta komponen gaji atas komplain yang diterima. 18).Batas waktu komplain gaji adalah satu hari setelah gaji diterima oleh karyawan.

\section{Prosedur pencatatan gaji}

Prosedur pencatatan gaji terdiri dari: 1).Semua dokumen yang berhubungan dengan gaji meliputi daftar kehadiran karyawan, daftar gaji, surat perubahan gaji, surat potongan gaji karyawan, surat keterangan gaji karyawan, daftar gaji, dan rekap gaji harus disimpan oleh bagian HRD, 2).Daftar gaji yang telah diotorisasi akan direkap kedalam rekap gaji bulanan. 3). Setiap perubahan gaji karyawan harus dicatat oleh bagian HRD. 4).Rekap gaji yang telah selesai dibuat akan diotorisasi oleh kepala bagian HRD. 5).Rekap gaji yang telah dibuat dan diotorisasi akan diserahkan ke bagian akuntansi untuk di catat sebagai biaya gaji karyawan pada periode tersebut. 6).Rekap gaji yang telah di buat serta diotorisasi juga diserahkan kepada manajemen sebagai bentuk pertanggungjawaban proses penggajian. 7).Setiap komplain gaji harus di catat oleh bagian HRD. 8).Setiap kesalahan gaji harus dicatat oleh bagian HRD. 9).Semua proses penggajian diawasi langsung oleh manajemen perusahaan.

\section{Flowchart yang di rekomendasikan.}

Berikut ini adalah flowchart yang direkomendasikan peneliti, flowchart ini dibuat dengan sederhana agar mudah untuk dipahami : 

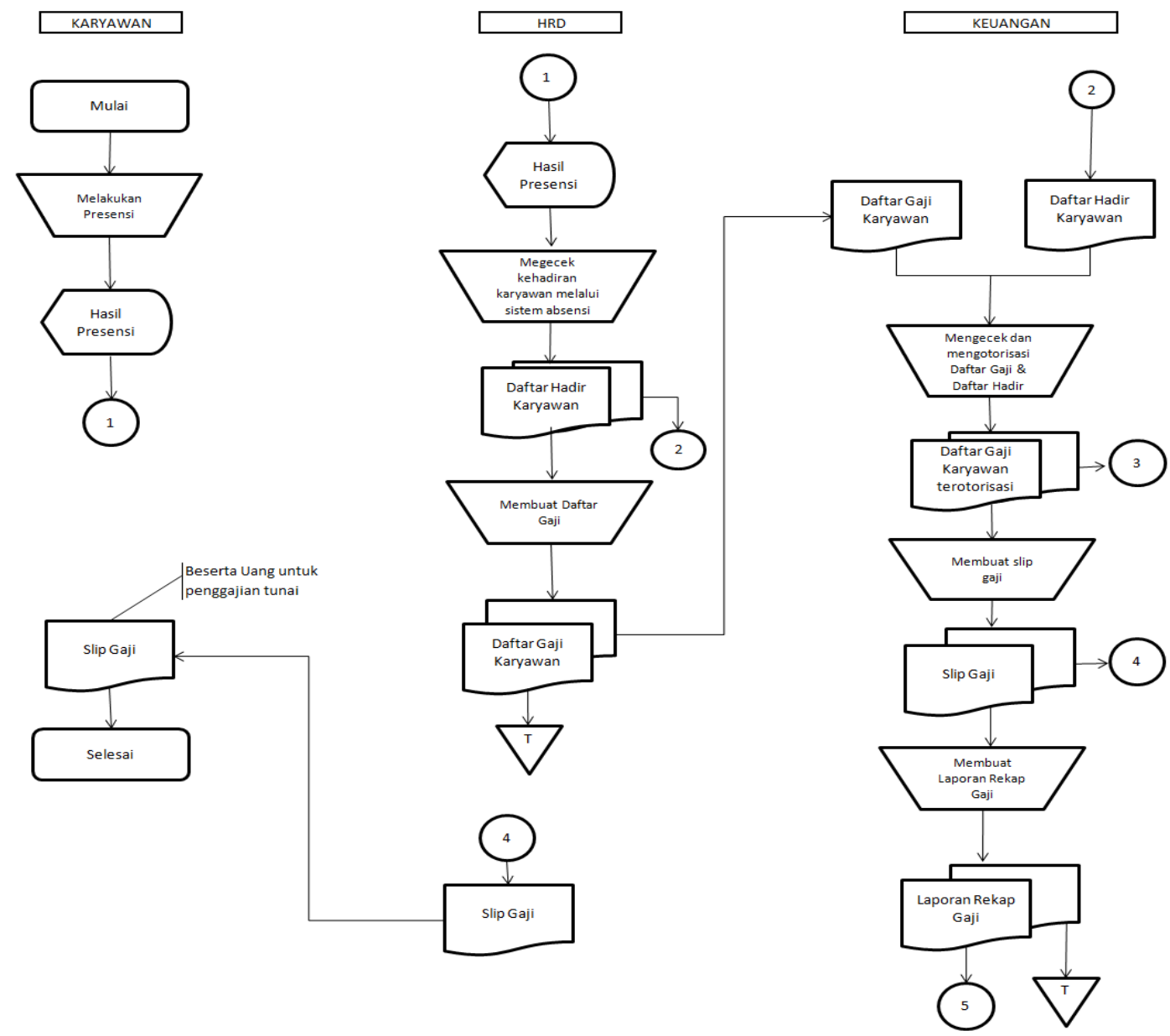

Gambar 3. Rekomendasi Flowchart CV Surya Jaya Abadi
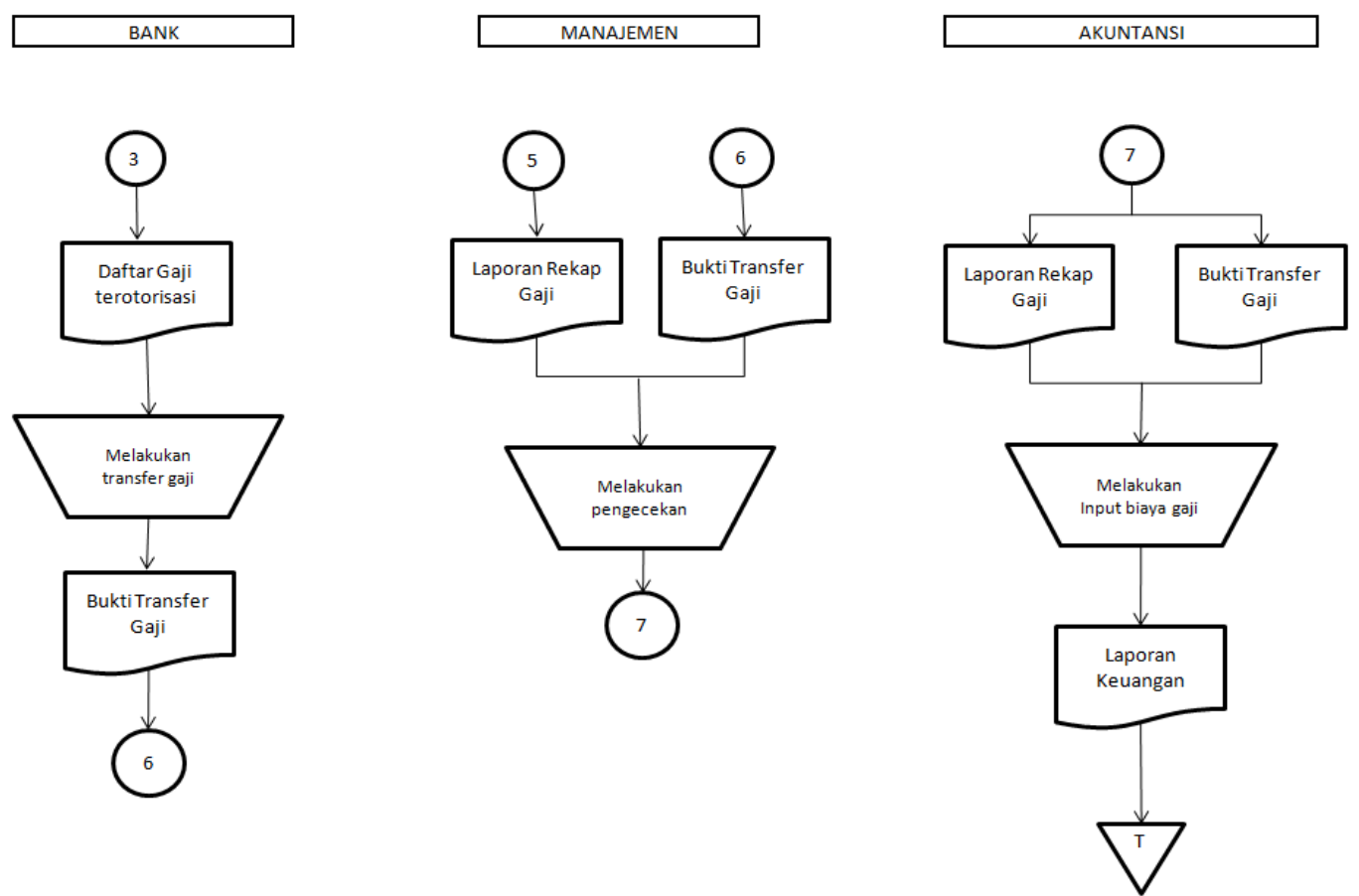

Gambar 4. Rekomendasi Flowchart CV Surya Jaya Abadi 


\section{KESIMPULAN DAN SARAN}

\section{Kesimpulan}

Sistem pengendalian internal penggajian di CV Surya Jaya Abadi sudah berjalan dengan cukup efektif, walaupun masih ada beberapa hal yang perlu diperbaiki terutama dalam hal struktur organisasinya yaitu pemisahan tugas dan wewenang.

CV Surya Jaya Abadi belum melakukan pemisahan tugas secara fungsional terhadap proses penggajian, seluruh proses penggajian dilakukan oleh bagian HRD mulai dari pencatatan waktu hadir, pembuatan daftar gaji, slip gaji dan distribusi gaji.

Permasalahan proses penggajian di CV Surya Jaya Abadi banyak disebabkan oleh kesalahan manusia seperti karyawan yang tidak mematuhi SOP absensi dan kesalahan input gaji serta perhitungan komponen gaji oleh bagian HRD.

Sistem penggajian yang terkomputerisasi pada CV Surya Jaya Abadi belum terhubung dengan sistem absensi, sehingga memerlukan ketelitian dalam penginputan gaji, hal ini juga berpengaruh terhadap meningkatkan resiko kesalahan gaji.CV Surya Jaya Abadi belum memiliki sistem penggendalian internal penggajian tertulis.

\section{Saran}

Peneliti memberi saran kepada CV Surya Jaya Abadi untuk memeperbaiki sistem pengendalian internal penggajian dalam hal pemisahan tugas dan wewenang untuk menghindari resiko kecurangan yang akan terjadi. Untuk mengurangi tingkat kesalahan gaji peneliti menyarankan untuk mempertegak mengenai SOP yang ada dalam hal ini adalah absensi melalui fingerprint dan memberikan konsekuensi apabila melanggar untuk menimbulkan efek jera.Dari sisi sistem penggajian peneliti menyarankan untuk sistem penggajian bisa langsung terhubung dengan sistem penggajian agar mengurangi tingkat kesalahan gaji.

Sistem pengendalian internal penggajian CV Surya Jaya Abadi belum memiliki prosedur yang tertulis, oleh karena itu peneliti merekomendasikan sistem pengendalian pengendalian internal penggajian tertulis yang telah disusun oleh peneliti, sebagai bahan pertimbangan prosedur penggajian yang tertulis yang dapat dijadikan dasar proses penggajian.

\section{DAFTAR PUSTAKA}

Hardhanto, Sulung Yogy et al. (2015). Analisis sistem pengendalian internal penggajian karyawan pada PT. BPR Prisma Dana. Jurnal Berkala Ilmiah Efisiensi, 15(5), 119-131.

Husniyah, Aminatul Husniyah et al. (2015). Analisis pengendalian internal pada sistem penggajian karyawan (Studi pada RSUD Dr. H. Moh. Anwar Sumenep). Jurnal Administrasi Bisnis, 28(2), 1-10.

Indrawan, I Komang Juni, et al. (2017). Analisis sistem pengendalian intern pada penggajian karyawan PT PLN (Persero) Area Bali Utara. E-Journal S1 Ak Universitas Pendidikan Ganesha, 8(2), doi: http://dx.doi.org/10.23887/jimat. $\mathrm{v} 8 \mathrm{i} 2.11052$

Jalunto et al. (2018). Studi penerapan pengendalian intern sistem akuntansi penggajian outsourcing. Jurnal Ilmiah UNTAG, 7(1), 63-81.

Mulyadi. (2016). Sistem Informsi Akuntansi. Salemba Empat: Jakarta

Pane, Rosdiana. (2015). Analisis pengendalian internal pada proses penggajian di CV Genta Shamballa. Jurnal Ekonomi dan Kewirausahaan, 9(3), 154-164.

Putri, Nabila Aulia et al. (2017). Analisis sistem akuntansi penggajian pada karyawan dalam menunjang pengendalian internal pada CV Nusantara Kubah Mandiri Trenggalek Tahun 2016. Simki-Economic, 1(4), 1-15.

Wulandari, Retno. (2018). Analisis sistem pengendalian internal penggajian pada PT Usaha Tani Maju. Simki-Economic, 2(8), 1-13. 